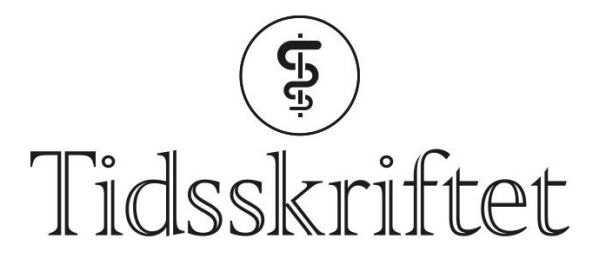

DEN NORSKE LEGEFORENING

\title{
Migrenebehandling hos barn
}

FRA ANDRE TIDSSKRIFTER

LISE SKOGSTAD LOFTSGAARD

Tidsskriftet

Forebyggende medisiner mot migrene hos barn bør forbeholdes dem som er hardest rammet.

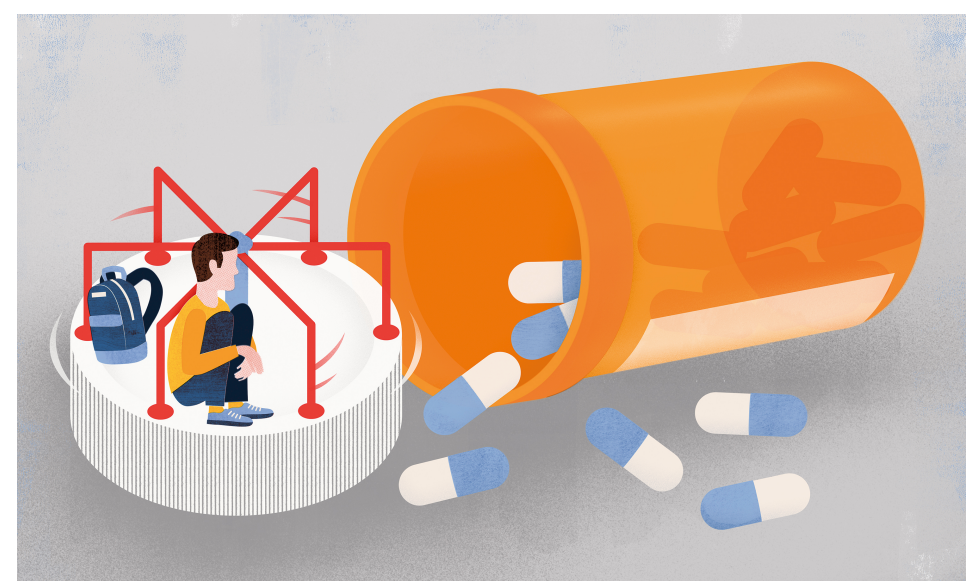

Illustrasjon: Ikon Images / NTB Scanpix

En systematisk oversiktsartikkel og nettverksanalyse har sett på effekten av forebyggende migrenemedisin hos barn (1). I alt ble 23 kliniske studier med til sammen litt over 2 ooo pasienter gjennomgått. Legemidlene omfattet både antiepileptika, antidepressiver, kalsiumkanalblokkere, antihypertensiver og kosttilskudd, og man skilte mellom korttidseffekter (dvs. effekt som oppsto etter innen fem måneder) og langtidseffekter.

Bare to medikamenter, propranolol og topiramat, hadde signifikant korttidseffekt sammenlignet med placebo, med 95\% konfidensintervall på henholdsvis o,03-1,17 og o,03-1,15, men prediksjonsverdien var lav. Ingen av de forebyggende medisinene hadde signifikant langtidseffekt sammenlignet med placebo.

- Denne studien støtter ikke opp under det at noen av de vurderte forebyggende medikamentene gir signifikant effekt mot barnemigrene, sier Kristian Sommerfelt, som er professor og overlege ved Barne- og ungdomsklinikken ved Haukeland universitetssjukehus.

- Hos de aller fleste barn med migrene vil dager med migrene være langt færre enn dager uten. Et forebyggende medikament vil derimot typisk ha bivirkninger alle dager.

Propranolol og topiramat kom nærmest en forebyggende effekt i studien, men begge disse medikamentene gir ofte bivirkninger. Man bør derfor være tilbakeholden med 
forebyggende behandling mot migrene hos barn, med mindre anfallshyppighet og tyngde er stor. Bare da vil en individuell tilnærming med flere medikamenter være aktuell, sier Sommerfelt.

\section{LITTERATUR:}

1. Locher C, Kossowsky J, Koechlin $\mathrm{H}$ et al. Efficacy, safety, and acceptability of pharmacologic treatments for pediatric migraine prophylaxis a systematic review and network meta-analysis. JAMA Pediatr 2020; 174:341. [CrossRef]

Publisert: 22. mai 2020. Tidsskr Nor Legeforen. DOI: 10.4045/tidsskr.20.0222

(C) Tidsskrift for Den norske legeforening 2020. Lastet ned fra tidsskriftet.no 